\title{
Electrical Power Consumption Monitoring on Filament 3D Printer Using Web Based
}

\author{
Adi Kurniawan Saputro*,Fifi Ayu Rochmakhayatin, Haryanto, and Miftachul Ulum \\ Electtrical Engineerings, Faculty of Engineering, Trunojoyo University, Bangkalan Indonesia
}

\begin{abstract}
In Indonesia, the use of 3D printers is gaining popularity in industrial processes, because the use of 3D printers in the manufacture of objects takes a relatively shorter time. However, in Indonesia, there is still very little information about the results of the $3 \mathrm{D}$ printer process, such as how much strength the object produced from the process, the accuracy and others. In this research, 10 experiments parameters such as current, voltage, power and energy was testing to get electrical power consumption. If time of usage parameter is added, then the results can be used to calculate how much bill you should pay to operating this equipment. The result shown that monitoring the consumption of electrical power used by $3 \mathrm{D}$ printer devices can be done using the PZEM-004T sensor with an accuracy level that is read by the sensor of $99.472 \%$ at reading the voltage value where the sample value obtained is $207 \mathrm{~V} \mathrm{AC}$ and the voltage value that is read on the digital multi tester device is $208.1 \mathrm{~V} \mathrm{AC}$ so that the difference obtained is only $1.1 \mathrm{~V} \mathrm{AC}$.
\end{abstract}

Keywords: 3D printers, power consumption, PZEM-004T sensor

\section{Introduction}

Information technology has developed from time to time and these developments aim to facilitate human work in various sectors such as the industrial sector. Technology in the industrial sector is used for several things, such as accelerating the production of product components, one of the technologies that support this is $3 \mathrm{D}$ printers [1]. $3 \mathrm{D}$ printer is a development in technology that is very popular and is present in various parts of the world. 3D printers create three-dimensional objects from CAD models or digital 3D models, 3D printers print threedimensional objects through a variety of processes in which materials are stored, combined or compacted which are organized by a computer to create threedimensional objects, with materials added together (such as plastic, liquid or powdered grains that are fused into a three-dimensional object).

In the process of making $3 \mathrm{D}$ printer objects, of course, it requires stable power consumption to minimize damage. Some of the parameters used to determine the state of the 3D printer are voltage, current and power values [2]. From this information, a study on information analysis was made which aims to determine the amount or amount of power consumption required by a 3D printer to create an object [3] .

Therefore, to overcome these problems the author will monitor the power consumption of the use of $3 \mathrm{D}$ printers in real time, this system uses ESP 32 as the main controller and the PZEM-004T sensor to read the power connected to the 3D printer via Arduino software $[4,5]$. After that, monitoring via the web with WIFI connectivity is done without having to change and configure the program on the Arduino application, so that the system will automatically connect to the WIFI device that was previously set on the Arduino software without having to change the SSID and password on the Arduino program, the voltage data that has been obtained will be compared with the data obtained through measurement with a multitester [6].

This research is supported by several previous studies conducted by S. Anwar, T. Artono, and A. Fadli, (2019) in the journal entitled " Pengukuran Energi Listrik Berbasis PZEM-004T " research that discusses the measurement of electrical energy using the PZEM004T module [7]. Because in the module there is already a current and voltage sensor so that the use of electrical energy becomes more efficient and in its use there is no waste of electrical energy. With the previous research, a study entitled "Electrical Power Consumption Monitoring on Filament 3D Printing" was made which is expected to help the analysis to calculate the power requirement to create a certain size object with a $3 \mathrm{D}$ printer [8].

\footnotetext{
* Corresponding author : adi.kurniawan@trunojoyo.ac.id
} 


\section{Materials and Method}

\subsection{D printing}

3D Printer is the process of making 3-dimensional objects using a CAD model (computer-aided design), the manufacture is done by providing several layers of printed material (layer by layer) so that it is fast, gets good details and is easy in the process [9]. The working principle of $3 \mathrm{D}$ printing is explained in the paragraph below [3] :

1 Create a 3D model

In the process of modeling a 3D object using various special software to be able to design a 3D model that is used to support the printer in the process of printing the object.

2 Printing process

The basic principle starts with the machine reading the pattern and design process, then the layering process is carried out in stages. When the process is complete, the object can be used.

3 Finishing process

At the very last stage is finishing. Next complete the parts that are not printed so that the object becomes complex. In the finishing process, there are various techniques, including multiple material techniques

\subsection{Basic electrical quantities}

Some of the basic electrical quantities described are parameters to be controlled by the system.

\subsubsection{Voltage}

Voltage is a quantity that shows the amount of potential energy difference between two points. Voltage has units of volts with the symbol V. Voltage can also be defined as the amount of energy in joules for each charge in coulombs.

$$
\mathrm{V}=\mathrm{dW} / \mathrm{dQ}
$$

\subsubsection{Current}

Current is a quantity that shows the rate of change of charge per unit of time. The current has units of amperes with the symbol A.

$$
\mathrm{I}=\mathrm{dQ} / \mathrm{dt}
$$

\subsubsection{Power}

Power is the energy expended to do work. In an electric power system, power is some amount of energy that will be used to do work or a business. Electrical power is usually expressed in the general unit Watt. Electrical power is the amount of electrical energy used by several electrical equipment in a unit of time. Electrical power is denoted by the symbol P and has units of watts (W). In the international system (SI), the unit of electric power is the joule per second $(\mathrm{J} / \mathrm{s})[10]$. Mathematically, electric power can be determined by the following equation.

$$
\mathrm{P}=\mathrm{V} \times \mathrm{I}
$$

\subsubsection{Energy}

The energy used by an electric tool is the rate of use of energy (power) multiplied by the time during which the tool is used. When power is measured in watt hours, then:

$$
\mathrm{W}=\mathrm{P} \times \mathrm{t}
$$

\subsection{System Planning}

3 tool working system:

1 The monitoring tool that will be made will read data in the form of voltage, current, power and energy used by the $3 \mathrm{D}$ printer through the PZEM-004T sensor [5].

2 After the data is obtained, then the device that is connected to the modem will send the data to a web service via the internet.

3 Data that has been stored in the web service will be displayed on the web monitoring in the form of graphs and data tables.

\section{Flowchart system}

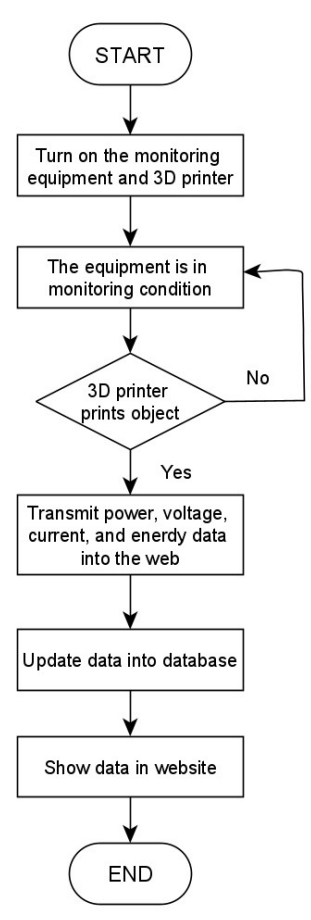

Fig. 1. Flowchart System

From the diagrams made in this study, to get the value of current, voltage, time, and power where to generate data all of that can be seen on a computer screen that has been previously monitored. Furthermore, which will be used at this stage of research, data will be collected and then analyzed to produce accurate data. 


\section{Hardware design}

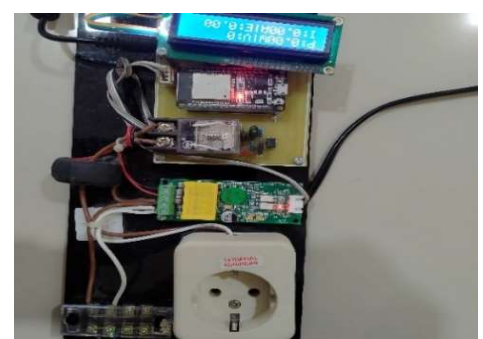

Fig. 3. Hardware

From the picture below, it is explained in outline that the $220 \mathrm{~V}$ AC power goes to the adapter and relay [10]. The adapter used is $9 \mathrm{~V} 2 \mathrm{~A}$ and the voltage is lowered through the buck converter $\operatorname{lm} 2956$ to $5 \mathrm{~V}[12,3]$.After that, the relay connects to the PZEM-004T module which can read and is equipped with a microcontroller to retrieve data because it already has current, voltage, power, and current sensors. and the energy is taken from a memory address that already exists in the microcontroller system with the aim of displaying a monitoring followed by a $3 \mathrm{D}$ printer connected to the LCD output, relay, and web hosting. So this system is automatic where when monitoring is on and connected to a $3 \mathrm{D}$ printer, the data will automatically go directly to the web automatically when someone uses a 3D printer.

\section{System Implementation and Testing}

\subsection{How the equipment works}

The working process of the tool goes through several stages including the following:

1 Connect the monitoring device to the power source Connect the 3D printer with the monitoring tool (hardware5.) (the power source of the 3D printer is taken from the source of the monitoring tool)

2 Turn on the modem then connect the device to the WIFI network $($ ssid $=$ smart, password $=$ smart 123$)$

3 Go to the web page

4 3D printer program to create an object.

5 Then the printing process occurs and the data information will automatically be entered into the web

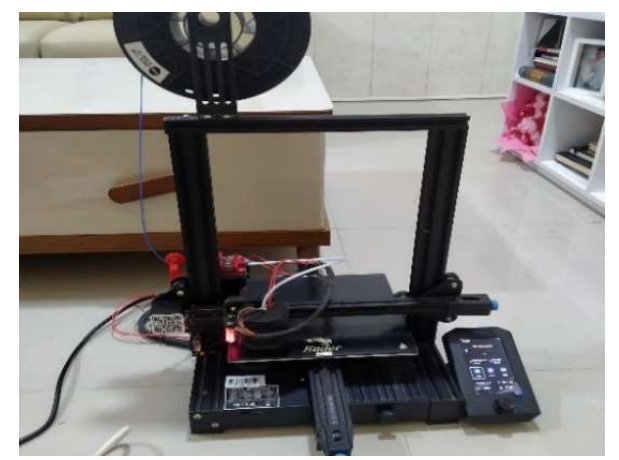

Fig.3. Printer 3D

\subsection{How the data transmited}

In the process of making $3 \mathrm{D}$ objects, 3D printers use voltage, current, and power which are monitored by the PZEM-004T sensor module through a monitoring tool. The monitoring tool sends data to the monitoring web in an automatic way when the monitoring tool is connected to the automatic switch the rlay will turn on and the data will enter the monitoring web. This is supported by the presence of ESP 32 which is in the monitoring tool which is equipped with a wifi module with the Arduino program so that it can send data to the server and display it via web monitoring [13][14][15][16].

\subsection{Sensor Testing}

In this test, several data have been obtained in the form of voltage and current data which are read by the PZEM-004T sensor module with a digital multi tester measuring instrument [17] [18] [19]. The following is a comparison table of the two data.

Table 1. Sensor Testing.

\begin{tabular}{|c|c|c|}
\hline Tools & Font & Spacing \\
\hline PZEM-00T & 207 & 0.60 \\
\hline $\begin{array}{c}\text { Digital } \\
\text { Multitester }\end{array}$ & 208.1 & 0.64 \\
\hline
\end{tabular}

It can be analyzed that the error value of the PZEM$004 \mathrm{~T}$ sensor with a multi tester [20] measuring instrument for voltage is as follows :

$$
\begin{aligned}
& \text { Eror }=|208,1-207| \\
& \text { Eror }=1,1 \text { Volt }
\end{aligned}
$$

\subsection{Data analysis}

In testing the equipment, 10 experiments were carried out to get data that was recorded and could be analyzed. The data is in the form of values from the recording of the $3 \mathrm{D}$ printer machine in the form of Current, Voltage and Power consumed by the 3D printer engine that is running and executing the object printing command. The following is a list of objects obtained when recording data on a $3 \mathrm{D}$ printer engine that is running and executing commands that are recorded in real time with a recording interval of every 30 seconds. In the recording, there is a difference in the amount of data obtained due to the different design models used to execute the $3 \mathrm{D}$ printer

The data of duration usage obtained below is taken from monitoring data from the web monitoring 3D printer. 
Table 1. Power and usage duration.

\begin{tabular}{|c|c|c|c|}
\hline NO & $\begin{array}{c}\text { Printed } \\
\text { Object }\end{array}$ & $\begin{array}{c}\text { Usage } \\
\text { Duration } \\
\text { (minutes) }\end{array}$ & $\begin{array}{c}\text { Power Average } \\
\text { (watt) }\end{array}$ \\
\hline 1 & Endcap & 36 & 109,7347 \\
\hline 2 & Clothespin & 52 & 136,6092 \\
\hline 3 & Glass & 40 & 128,4852 \\
\hline 4 & Square & 9 & 99,4263 \\
\hline 5 & Square & 10 & 101,168 \\
\hline 6 & Square & 11 & 102,504 \\
\hline 7 & $\begin{array}{c}\text { Human } \\
\text { figure }\end{array}$ & 43 & 100,076 \\
\hline 8 & Bowl & 23 & 87,2946 \\
\hline 9 & Bowl & 18 & 101,563 \\
\hline 10 & Bowl & 14 & 100,41 \\
\hline
\end{tabular}

From the table above, it is known that the ten experiments were carried out for no more than one hour in the process of processing an object

\section{Conclusion}

Based on the experiments that have been carried out, it can be concluded that monitoring the consumption of electrical power used by $3 \mathrm{D}$ printer devices can be done using the PZEM-004T sensor with an accuracy level that is read by the sensor of $99.472 \%$ at reading the voltage value where the sample value obtained is $207 \mathrm{~V}$ AC and the voltage value that is read on the digital multi tester device is $208.1 \mathrm{~V} \mathrm{AC}$ so that the difference obtained is only $1.1 \mathrm{~V} \mathrm{AC}$.

While the current value is also obtained with an accuracy of $93.75 \%$ on the current value reading where the sample value obtained is $0.60 \mathrm{~A}$ and the current value read on the digital multi tester device is $0.64 \mathrm{~A}$ so that the difference obtained is only 1.1 VAC. The results of the 10 experiments that have been carried out have obtained the average power used by the $3 \mathrm{D}$ printer in each experiment as shown in the table.

\section{References}

[1] B. Satyanarayana and K. Jaya, Component replication using $3 D$ printing technology, Procedia Mater. Sci., vol. 10, no. Cnt 2014, pp. 263-269 (2015)

[2] C. Widiasari, F. Rendy, and W. Styorini, Sistem monitoring daya listrik dan pengontrolan perangkat elektronik berbasis iot, pp. 342-349 (2020)

[3] B. Internet and O. F. Things, Rancang bangun alat monitoring biaya listrik terpakai berbasis internet of things (iot), pp. 1-11

[4] H. Airlangga and N. Utomo, Kelembapan pada fermentasi tempe menggunakan arduino berbasis android fakultas teknik universitas 17 agustus 1945 surabaya (2019)
[5] F. Nur and S. Setiawidayat, Alat monitoring pemakaian energi listrik berbasis android menggunakan modul pzem-004t,vol. 01, no. 01, pp. 157-162 (2017)

[6] A. Wahid, Analisis kapasitas dan kebutuhan daya listrik untuk menghemat penggunaan energi listrik di fakultas teknik universitas tanjungpura

[7] S. Anwar, T. Artono, N. Nasrul, D. Dasrul, and A. Fadli, Pengukuran energi listrik berbasis pzem004t, Pros. Semin. Nas. Politek. Negeri Lhokseumawe, vol. 3, no. 1, pp. 272-276 (2019), [Online]. Available: http:/ejurnal.pnl.ac.id/index.php/semnaspnl/article/view/ 1694

[8] R. Pramuditya, Y. E. Putri, C. B. Nurcahyo, A. K. Penelitian, and A. A. S. Penghawaan, Analisa perbandingan biaya kebutuhan dan penggunaan energi hotel yusro jombang, vol. 1, no. 1 (2012)

[9] K. S. Putra, S. Ds, U. R. Sari, and S. Ds, Pemanfaatan teknologi $3 d$ printing dalam proses desain produk gaya hidup, pp. 1-6 (2018)

[10] A. A. Hutasuhut, Analisa perbandingan switch mode power supply ( smps) dan transformator linear pada audio amplifier, vol. 1, no. 2, pp. 90102 (2017)

[11] 1A. Firmansyah, Perancangan sistem charger battery berbasis mikrokontroller dengan rangkaian buck converter (2018)

[12] I. N. W. Satiawan, Perancangan sistem charger battery berbasis converter

[13] A. Imran, Pengembangan tempat sampah pintar menggunakan esp32, vol. 17, no. 2 (2020)

[14] I. Abed and H. Naser, ESP32 Microcontroller based smart power meter system design and implementation, Al-Rafidain Eng. J., vol. 25, no. 2, pp. 137-145 (2020)

[15] V. Pravalika and C. Rajendra Prasad, Internet of things based home monitoring and device control using esp32, Int. J. Recent Technol. Eng., vol. 8, no. 1 Special Issue 4, pp. 58-62, (2019)

[16] A. Maier, A. Sharp, and Y. Vagapov, Comparative analysis and practical implementation of the ESP32 microcontroller module for the internet of things, (2017)

[17] Suhanto, A. Setiyo Prabowo, R. Indrianto Sudjoko, and W. Suryono, The electrical energy usage of monitoring system at real-time using IoT as the primary policy of energy efficiency, IOP Conf. Ser. Mater. Sci. Eng., vol. 909, no. 1, (2020)

[18] I. . A. M.Haqqu, Rancang bangun sistem monitoring konsumsi daya listrik dan pemutus daya otomatis berbasis internet (2018)

[19] I. Y. Cahyono et al., Pembuka kap dan bagasi mobil menggunakan smartphone berbasis bluetooth (2018)

[20] H. Baehaqi, Sistem kwh meter digital menggunakan modul pzem-004t," vol. 16, no. 1, pp. 29-34 (2019) 